Running head: NEONATICIDE AND DENIAL OF PREGNANCY

\title{
Analysis of the relationship between neonaticide and denial of pregnancy using data
} from judicial files version

\section{Natacha Vellut ${ }^{1}$, Jon M Cook ${ }^{2}$, Anne Tursz ${ }^{2}$}

${ }^{1}$ Cermes3 (Centre de Recherche Médecine, Sciences, Santé, Santé mentale et Société)

45 rue des Saints Pères, 75270 Paris Cedex 6, France

E mail : natacha.vellut@parisdescartes.fr

${ }^{2}$ Cermes3 (Centre de Recherche Médecine, Sciences, Santé, Santé mentale et Société)

Site CNRS, 7 rue Guy Môquet, 94801 Villejuif, France

E mail : cook@vjf.cnrs.fr

\section{Corresponding author}

Anne Tursz

Cermes3/ Inserm U988

Site CNRS, 7 rue Guy Môquet, 94801 Villejuif, France

Tel: + 33-1-49 583640

Fax: + 33-1-49 583438

\section{E mail : tursz@vjf.cnrs.fr}

\section{Acknowledgements}

The authors wish to thank:

The funding agencies: Directions générales de l'Action sociale et de la Santé, Mission de recherche «Droit et justice » du Ministère de la Justice, Institut national de la Santé et de la Recherche médicale, Observatoire national de l'Enfance en danger, Région Île de France,

Fondation Wyeth pour la Santé de l'Enfant et de l'Adolescent.

3 The court staff that made the study possible.

4 Pascale Gerbouin-Rérolle who was responsible for coordinating the fieldwork. 
Objectives: Using judicial files on neonaticides, 1) examine the frequency of the association between neonaticide and denial of pregnancy; 2) assess the accuracy of the concept of denial of pregnancy; 3) examine its usefulness in programs to prevent neonaticides.

Methods: Quantitative and qualitative analysis of data collected from judicial files during a population-based study carried out in 26 courts in 3 regions of France over a 5-year period. Results: There were 32 cases of neonaticides identified; 24, perpetrated by 22 mothers, were solved by police investigation. Aged 26 years on average, the mothers had occupations that resembled those of the general population and 17 had jobs, 13 were multiparous and 11 lived in a couple relationship. No effective contraception was used by women in 20 cases.

Psychopathology was rare but mothers shared a personality profile associating immaturity, dependency, weak self esteem, absence of affective support, psychological isolation and poor communication with partners. No pregnancy was registered nor prenatal care followed. Two (perhaps 3) pregnancies were unidentified until delivery. No typical denial of pregnancy was observed in the other cases. Pregnancies were experienced in secrecy, with conflicting feelings of desire and rejection of the infant and an inability to ask for help. Those around the mothers, often aware of the pregnancy, offered none. In the absence of parallel clinical data, it is not possible to calculate the frequency of the association neonaticide-denial of pregnancy. Conclusions: The term "denial of pregnancy" poorly describes the complexity of emotions and feelings felt by perpetrators of neonaticides. The term is used differently by different professionals. It gives a pathologizing label to women while absolving those around them and has little operational value in preventing neonaticides. It appears necessary to replace the term "pervasive denial” by "unknown pregnancy" and "concealed pregnancy" by "secret pregnancy".

Key words: neonaticide, population-based study, pregnancy denial, judicial data, psychology. 


\section{Analysis of the relationship between neonaticide and denial of pregnancy}

\section{using data from judicial files}

In many countries, including France, media regularly report cases of neonaticide (homicide within the first 24 hours of life), especially the discovery of multiple neonaticides. In the press, as well as in testimony by experts called in during trials, there is a regular association made between neonaticide and denial of pregnancy. This is also true in scientific publications. For example, Miller (2003, p. 81) states that "Neonaticide is often preceded...by denial and/or concealment of pregnancy." This reference to denial during cases of neonaticide raises questions of an ethical nature since the concept is often used by judges and especially by lawyers - sometimes aided by the experts themselves - without being sufficiently supported by scientific evidence. Furthermore, the word denial is subject to various meanings in everyday discourse or in different currents in psychology, psychiatry and psychoanalysis. In the present article, we examine the possibility of calculating the frequency of the association between denial and neonaticide, the rigor of the concept of denial as presently defined, and the likelihood of a pathologization or labeling of women brought about by the use of the term. These questions are addressed using data on neonaticides reported to the judicial system in France and collected in a geographically-based epidemiological study that demonstrated the underestimation of the frequency of neonaticides in the country (Tursz \& Cook, 2011). Through the analysis of different points of view and numerous documents from the judicial files, we identify and describe apparent situations of denial and analyze the contribution our results make to understanding the concept of denial and the pertinence of definitions presently in use. These definitions have important implications in caring for women, for the judicial management of cases of neonaticide, and for prevention. Thus, a brief overview of currently used definitions is needed before presenting the study methodology and results. 


\section{Definitions of Denial}

As a mental process, "Denial, in and of itself, is a perfectly normal and ubiquitous phenomenon. In fact, it is impossible to draw a definitive line between normal and pathological denial" (Stotland \& Stotland, 1998, p. 248). For some authors, denial implies first the recognition of a reality, then its active but unconscious rejection, a refusal to accept its existence (Bardou, Vacheron-Trystram, \& Cheref, 2006; Spinelli, 2001). Others consider this a relatively conscious adjustment mechanism (for example, Brezinka, Huter, Biebl, \& Kinzl, 1994). The concept of denial of pregnancy is multidimensional and includes notions of levels of consciousness, psychopathology and temporality (linked to the date the pregnancy was discovered).

According to Miller (2003), there are three types of pregnancy denial: Affective denial "occurs when a woman acknowledges intellectually that she is pregnant but experiences very few or none of the accompanying emotional or behavioral changes" (p. 82). Affective denial is associated with feelings of detachment from the infant. Pervasive denial "occurs when not only the emotional significance but the very existence of the pregnancy is kept from awareness" (p. 84). Weight gain, amenorrhea, and breast changes may not be present or may be misconstrued; even labor pains may be misinterpreted. Partners and families may also fail to notice pregnancies and there is a collective response of denial among those around the woman. Psychotic denial occurs when "physical symptoms and sign of pregnancies generally occur but are misinterpreted, sometimes in bizarre fashion" (p.85). Contrary to non psychotic women, these mothers do not conceal their pregnancy and those around them do not participate in denying the pregnancy.

While Miller, in discussing "pervasive denial", leaves a margin of uncertainty as to the constancy of clinical signs (as suggested by the repeated use of the word "may"), Beier et al propose stricter criteria for justifying the assumption of pregnancy denial such as the 
102

103

104

105

106

107

108

109

110

111

112

113

114

115

116

117

118

120

121

122

123

124

125

126

subjective certainty of the pregnant woman that she is not pregnant, unguarded behavior around others that could lead to discovery of a pregnancy, visits to the doctor for pregnancytypical symptoms, lack of preparation for birth, misinterpretation of labor pains and surprise at the birth (Beier, Wille, \& Wessel, 2006, p. 724). The problem is less-well defined for others: "There is no clear dividing line between conscious coping and unconscious defence mechanisms ....”(Brezinka et al., 1994, p. 6).

Many authors (for example Friedman, Heneghan, \& Rosenthal, 2007; Friedman \& Resnick, 2009; Beier et al., 2006), differentiate denied pregnancy from concealed pregnancy: "In contrast to the denial of pregnancy, concealment of pregnancy occurs in women who know that they are pregnant and actively conceal pregnancy from family, partners, friends, teachers, and coworkers" (Friedman et al., 2007, p. 117). Wessel, Gauruder-Burmester, \& Gerlinger (2007) define pregnancy concealment as a situation in which the woman is aware of her pregnancy, often from an early stage. But for Miller (2003), "Pregnancies denied are also pregnancies concealed" (p. 84).Yet Friedman and Resnick (2009) note there are "several subtypes of both denial and concealment of pregnancy" (p. 45). In studies carried out in obstetrics departments, the diagnosis of denial was based on the date of "discovery" of the pregnancy by the woman, and a threshold suggested: either 20 weeks of amenorrhea (Beier et al., 2006; Wessel \& Buscher, 2002), or between 21 and 26 weeks of amenorrhea (Brezinka et al., 1994).

By and large, there is no agreed definition for denial of pregnancy and no agreement on the relationship between deliberate concealment and pregnancy denial but the great rarity of pervasive denial has been demonstrated in population-based studies: 1 case for 2455 pregnancies in a prospective study carried out in all obstetrical facilities in an area of Berlin in 1995-96 (Wessel \& Buscher, 2002); 1 for 2500 in a retrospective and hospital-based Welsh study (Nirmal, Thijs, Bethel, \& Bhal, 2006). Since these studies were carried out in clinical 
settings, they excluded women who did not deliver under professional care, who may have delivered in a clandestine manner, and who were occasionally perpetrators of neonaticide.

\section{Legal Background}

\section{Legislation on Homicide}

Since 1994, the concept of infanticide in France is no longer distinct from the rest of child homicides. The penal code groups together all homicides of children under 15 years of age and there are neither separate statistics nor specific sentences for infanticides. The French Penal Code provides that "Persons suffering, at the time of their acts, from a psychiatric or neuropsychiatric disorder that abolished their judgment or the control of their acts" are not criminally responsible. In cases of people suffering a "disorder that altered their judgment or hindered the control of their acts ... the court takes this circumstance into account when determining the sentence and how it is to be carried out" (Article 122-1 - lines $1 \& 2$ ). Expert psychiatrists must answer the question of whether or not there was an abolishment or alteration of judgment. They must also determine if the subject examined has any mental or psychological abnormalities and whether these may be related to the alleged offense. Expert psychologists are asked by the court to submit the subjects to any examinations, interviews and tests useful for understanding their intelligence, manual dexterity, attention state, affectivity and disposition and to infer all data useful for understanding the motivations behind their acts.

\section{Legislation on Reproductive Health}

Since the 1970s, declaring a pregnancy to the government health administration is obligatory and confers rights to maternal leave and prenatal benefits, subject to a number of mandatory prenatal visits to the doctor. Since 1967, French legislation authorizing contraception has provided a number of measures for dealing with unwanted pregnancy (by its prevention or termination) while taking into account the special case of minors 
152 (prescription of contraceptive pills without parental consent, anonymity and free service in

153 family planning centers). Abortion was legalized in 1975 and can be carried out within the

154 first 12 weeks following the last menstruation. Since 2000, emergency contraception

155 (“morning after pill”) can be given by a school nurse to a minor student. Anonymous

156 childbirth refers to the possibility of a mother not revealing her identity during a delivery.

157

158

159

160

161

162

163

164

165

166

167

168

169

170

171

172

173

174

175

176

\section{Population and Methods}

This analysis of neonaticides is part of a research project carried out in a large geographical population in France on "suspicious infant deaths" (Tursz, Crost, GerbouinRérolle, \& Cook, 2010; Tursz \& Cook, 2011). In the context of this study, an expert advisory committee was assembled, composed of representatives of the judicial system, pediatrics, forensic medicine, pathology, maternal and child health, psychology, and epidemiology. This study was approved by the French Data Protection Authority (CNIL).

\section{Cases Included in the Study and Documents Used}

A retrospective study was carried out in 26 of 27 courts (one small court refused to participate) in 3 regions of France: Brittany, Île de France (Paris Region), and Nord-Pas-deCalais. These regions have very different socio-economic characteristics and rural/urban composition. During the study period, there were 1,286,253 live births, comprising $34.6 \%$ of all births from the 22 regions of continental France (INSEE, Annual). Included in the study were all cases of infants dying on the day of birth during a five-year period (1996-2000) that were submitted to the courts by the State prosecutors' offices in the three regions. This period was chosen so judicial proceedings would be concluded at the time of data analysis. Complete court case data cover the period from 1996 to 2008, due to often lengthy investigations.

The study was carried out at all levels of the judicial system, including criminal and appellate courts. Following identification and selection of cases using computer tools available in each court, judicial files were obtained and data entered into individual 
anonymous questionnaires by the research team (a field coordinator and two trained investigators). Each file was exhaustively examined and several documents were analyzed: transcripts of interviews by police and interrogation by the investigating judge of the mother and witnesses (mother's companion or husband, family members, friends, work colleagues, neighbors, first responders at the scene of the newborn's death); prosecutor's charges; the indictment; expert reports by psychiatrists and psychologists; results of personality tests; report of the forensic examination of the infant.

\section{Analysis}

In order to analyze each file, criteria of pregnancy denial from international publications were used: date of discovery of the pregnancy by the mother and those around her, medical declaration and monitoring of the pregnancy, adaptations in behavior, signs of pregnancy and birth pains, preparation for birth, the presence and nature of emotions and thoughts connected with the pregnancy, and the mental representation formed of the child. A data base of texts was created using Nvivo $8^{\odot}$ (a program for qualitative analysis) to enable exploration and comparison of data from various documents using content analysis. In addition to variables on the progress of the pregnancy and elements constituting "denial", a preliminary examination was done of the emotional history of the women and their general psychological characteristics (Tursz, Simmat-Durand, Gerbouin-Rérolle, Vellut, \& Cook, 2011).

A 153 item questionnaire was constructed according to a typology of factors likely to explain the act of murder: factors linked to the personality of the mother, to the family and social context both at the time of the event and in the past, to the mental representation of the infant, to the pregnancy and how it was perceived and to factors preceding the act. The quantitative data from this questionnaire were analyzed using Modalisa $6^{\odot}$ (a program for creating and analyzing questionnaires). 


\section{Results}

There are 32 cases of neonaticide in the sample analyzed below (infants born alive and viable), 27 cases recognized as such by the courts and 5 identified by the expert advisory committee. Judicial inquiries on person or persons unknown were opened for 8 cases after the discovery of an infant corpse (or 2 in one case). Out of 24 solved neonaticides, 22 mothers were implicated, two having repeated the offense.

\section{Mothers' Characteristics}

Socio-demographic aspects. The mothers' median age was 26 , with the youngest

being aged 17 and the oldest 44 . Nearly two-thirds already had children before the offense.

Close to half, 10 of 22, lived in a couple relationship. These mothers were not physically

isolated, as only two lived with just their children. Only five mothers were without a professional activity, with one of these being out of work not by choice (Table 1). psychiatric assessments on 16 mothers (supplemented by a psychological assessment for 6 cases), and 19 exclusively psychological assessments. Four mothers were considered to have psychotic personalities, but the assessments were contradictory for 3 of them. Out of 16 218 mothers for whom a psychiatric assessment was ordered, all were found to be criminally responsible. However, 11 mothers were considered to have had altered judgment and control of their acts while committing the offense, although for one of these 11 mothers the psychiatric assessments were contradictory. These findings were felt by the experts to be related to the particular psychological context of delivery and/or the neurotic personality of 223 the mother, as shown in the conclusions of a psychiatric assessment: It is necessary ... to take into account the neurotic character of the personality, with mechanisms of avoidance and inhibition present during the committing of the offense, and the physical and psychological stress of a delivery experienced completely alone. 
This leads to the conclusion that it is appropriate to consider there was significant mitigation of responsibility. Indeed, there was alteration and hindrance of control of these acts. (Case of Ms. B).

\section{Reproductive History}

Parity. Only 9 of 22 mothers were primiparous. Information was unavailable on whether this was the first pregnancy for these 9 (Table 1). When information was available on prior pregnancies and deliveries, it was in order to point out problems or dysfunctions. Three mothers committed neonaticides or attempted neonaticides before the current offense for which they were indicted. Four mothers noted difficulties in dating their prior pregnancies because they were belatedly acknowledged, and one of these mothers may have had 'pervasive denial' of pregnancy.

Contraception. In 20 out of 22 cases, it was noted there was either total absence of any contraception by women, its cessation, irregular use or even its active refusal. Some young primiparous women did not use contraception out of fear of their own mothers (3 cases). Two women did not seem able to envisage the potential reproductive consequences of sexual intercourse. Contraception was often a source of conflict in couples who usually were not able to discuss contraception, let alone agree upon its use.

I talked about it to my wife. I told her it was really time to do something. For example, I was thinking about tubal ligation. There was the pill, but she didn't take it. My wife didn't give me an answer; you couldn't really talk to her in general. As soon as we started talking about contraception, she would leave.... I didn't insist....In spite of that and although I knew my wife took no contraception, I took no precautions to keep her from getting pregnant. I didn't want to use a condom. (Testimony, husband of Ms. H., mother of 6 living children and perpetrator of four neonaticides). 
He [her husband] would never have accepted an abortion; besides, I had a lot of trouble figuring out the exact terms of my pregnancies. In fact, it wasn't his problem, it was mine. I had problems with the pill, it gave me headaches. We had envisaged an IUD, but he didn't want it. He didn't want to hear anything about condoms, it was for me to handle things. (Hearing testimony, Ms. K.).

\section{The Discovery, Acknowledgement, and Experience of Pregnancy}

Registering of the pregnancy and prenatal care. None of the women registered their pregnancy, regardless of the time of its discovery. More than half the women (12 out of 22) knew they were pregnant before or at 20 weeks (Table 1). Prenatal care was very rare. Only 3 mothers had a pregnancy test, only 5 had medical visits related to their pregnancy, with 1 of these 5 going to the hospital only a few hours before delivering back at home, with dramatic consequences. One visited her general practitioner and another her occupational physician for reasons unrelated to pregnancy, but the health professionals did not detect their pregnancies. I saw Ms. N. in my office twice this year: February $22^{\text {nd }}$ and March $26^{\text {th }}$. March $26^{\text {th }}$ she came for immunizations. I had her disrobe and examined her but I didn't notice she was pregnant [Ms. N. delivered April 10 $\left.{ }^{\text {th }}\right]$. (Testimony, general practitioner). Seven mothers thought of getting an abortion during their pregnancy, but the legal time limit had passed for 5 of them. Only one mother planned giving birth anonymously. Five mothers said they had wished to keep the baby and planned neither abortion nor abandonment. Ten mothers took no steps to terminate pregnancy and made no statement on 271 this matter during judicial investigations. The pregnancies seem to have been experienced 272 during a period where time stopped, without anticipation of the birth of the baby. In addition, the rare medical personnel consulted were unable to help in any way. 
parents and sisters, and stated she didn't know she was pregnant. Her family and neighbors gave similar testimony. The expert psychologist referred to pregnancy denial. Ms. V. was a 31 year old primiparous woman still living with her parents. She gave birth at the home of her partner, the father of the baby. She and those around her (family, employer, colleagues) stated they did not know she was pregnant. She said she took the pill during her pregnancy, but she had had no prescriptions for at least 2 years according to her physicians and the police found two unused pregnancy tests at her home. No psychiatric or psychological expert reports were available for this case.

I was completely unaware I was pregnant. I had abdominal pains. I had seen my general practitioner who prescribed medicine for constipation. [...] I never had a pregnancy test because I never imagined I was pregnant. I always wore the same clothes and didn't have any particular symptoms. (Testimony by Ms. V.) Ms. W., 24 years old and pregnant for the fourth time, stated she had not known she was pregnant. Her family and professional circle said the same. However, the father had noticed she had put on weight. She went to the doctor who prescribed a diet. The psychiatric expert spoke of repetitive denial - the fire department (first responders) had intervened for a sudden home delivery during a preceding pregnancy. The doctor was not alerted by this preceding unmonitored pregnancy and did not notice the mother's fourth pregnancy. I hadn't realized I was pregnant. I usually have my periods during my pregnancies and that was the case this time. I am not in the habit of weighing myself, but I didn't have the impression I had gained weight, I could still get into my clothes. (Hearing Testimony, $1^{\text {st }}$ appearance of Ms. W. before the judge).

I feel we are faced henceforth with a classical context of true and complete pregnancy denial, which is recurring in this particular case. (Psychiatric expert assessment of Ms. W.) 
These three files give a relatively uniform description of the experience of the

pregnancy and its discovery at delivery, although the situation for Ms. V. is subject to caution, especially since expert assessment was lacking in her case.

The criteria of denial. There is broad heterogeneity in the experiences of pregnancy.

A complete set of criteria defining pregnancy denial was not found in any of the files. In 13 out of 22 judicial files, the usual physical signs of pregnancy were not mentioned. Normal amenorrhea of pregnancy was noticed and acknowledged by 11 mothers. Weight gain was noted in 15 files, but approximations were used: the woman "gained weight" or gained "some weight". Fetal movements were not mentioned in 7 files. They were felt by 9 mothers and not by 6 others. As for pains prior to and signaling delivery, they were not mentioned in 11 files and confused with other pains (most often linked to digestive pains) in 6 files. getting an abortion but decided to keep the baby. The pregnancy was the subject of fantasies: pictured what the baby would be like [...] I thought about the cradle [...] (Hearing testimony). I wanted to have a girl..., I pictured her at 3 years old with a pretty smile..., I saw myself with her in my arms or in a stroller..., my parents would have However, she did not seek prenatal care and did not prepare for the birth.

Ms. D. knew she was pregnant, her family knew it, the father knew it and asked her to get prenatal care for the pregnancy. "I didn't do any of that. I don't know why." (Testimony by Ms. D.) Her knowledge of the pregnancy and its signs - she felt the baby move, asked her daughter to touch the baby in her belly - led to no consequences in terms of getting an abortion or preparing for the birth: "I was just pregnant, that's all. [...] this pregnancy was 
beyond me $[\ldots]$ it was as though it wasn't me that was pregnant, like it was my sister for example". (Hearing testimony, $1^{\text {st }}$ appearance before the judge).

Ms. L. knew she was pregnant from the $4^{\text {th }}$ or $5^{\text {th }}$ week of pregnancy. She put on weight and her pregnancy "was visible" (Hearing testimony) but when she was asked about it, she denied being pregnant. She felt the baby moving and thought, "...bring a baby into the world" (psychiatric assessment) but also thought, "If I quit eating, the baby will leave by itself” (Testimony by Ms. L.).

In these conflicting situations, the mothers all adopted the same defense mechanism: secrecy. They took refuge in "silence". Statements like: "I couldn't speak to anyone about it" came back time and again in the discourse of several women. Three mothers spoke of a "mental block". This block is similar to a "retreating" into oneself, mentioned by 3 other mothers and may also be compared to a refusal to simply think about the pregnancy, as 7 mothers testified. While this refusal may resemble a conscious defense mechanism, including purposeful dissimulation of the pregnancy, it is sometimes much more complex to understand. I was going to talk to my husband but I didn't do it because I had a mental block, I don't know exactly why. In any case, I was blocked when I wanted to bring up the subject with him. (Hearing testimony, Ms. M.).

I rejected the idea of pregnancy from the beginning. [...] I refused to accept the idea of being pregnant. I rejected all the signs. (Hearing testimony, Ms. J.).

I finally started living with the idea I was carrying a baby in me. That was a difficult period, where I had to hide the pregnancy at every instant. (Testimony, Ms. E.). This refusal or the impossibility to plan, to anticipate, to imagine the consequences of the pregnancy was particularly evident in the files of 8 mothers. 
The desire for a child. The desire of a neonaticidal mother for a child elicited

numerous questions on the part of the police and the judges and led to investigations by expert examiners. Apart from the 3 mothers with unknown pregnancies, mothers often gave contradictory statements about this. Four subjective situations were noted: 4 mothers confirmed the rejection of their pregnancy and the future child; 8 said they wanted a child; 3 mothers vacillated between rejection and desire, expressing these two options in turn; 4 mothers gave no opinion.

I would have preferred to live my pregnancy alone [...] I wanted to keep the baby $[\ldots]$ I wanted that baby for me. (Testimony, Ms. O.).

I think the baby cried when it came out [...] if I kept it my life was finished, no more friends, no studies, I disappointed my family. [...] I decided not to keep it. I told myself that I had to find some plastic bags. (Testimony in police custody, Ms. I.) I never thought about abortion because I wanted the baby. I would have kept it even if I didn't want it in the beginning. (Hearing testimony, Ms. M.). I stand by the fact I hid the pregnancy from my spouse. [... I always told myself, that baby, I didn't want anything to do with that baby. (Testimony, Ms. M.).

Whether the child was desired or not, the mental representation of it was problematic in most cases. "I didn't want to look [at the baby after the birth] because I don't know what I would have done afterwards; if I had seen it, perhaps I would have kept it.” (Testimony in police custody, Ms. H.).

\section{The Mother's Family Circle}

While the family circle apparently did not know about the pregnancy in 7 cases, in all other cases, at least one close relative, or even the whole family, had strong suspicions or actual knowledge about the pregnancy. In 1/3 of cases, ignorance of the pregnancy was asserted: "I never noticed that my daughter was pregnant, I'm telling you [...] I'm a nurse's 
aide and I know what I'm talking about [...]"' (Testimony, mother of Ms. S.). However, when the pregnancy was learned about by those close to the mother, this sometimes occurred early on: "I bought the [pregnancy] test around November $11^{\text {th }}$ and it turned out positive [the mother delivered July 10]" (Witness testimony by Ms. D’s partner).

Family members may have had suspicions, and when faced with these, neonaticidal mothers denied they were pregnant. Nevertheless, these suspicions or this certainty did not prevent the tragic outcome of these pregnancies. Suspicions were sometimes so strong they were considered a form of complicity, to the point where the courts decided to charge three fathers (those of babies belonging to Ms. H., V., and W.), one maternal grandmother (mother of Ms. W.), a maternal uncle (brother of Ms. S.), and even the entire maternal family of Ms. D. with "involuntary homicide" or "failure to report a crime".

The absence of communication in couples that was mentioned concerning contraception includes all family relationships. It is difficult to know who - her relatives or the mother - was responsible for this lack of communication, but the atmosphere of silence and emotional isolation is clear. This silence was doubtless linked to fear felt by these women and expressed by 11 mothers. In 5 cases, this fear concerned the father of the baby, in 2 cases their own mother, in 2 cases the whole family, and in 2 cases those around them in general. I didn't confide in anyone. I didn't know what to do and I let the situation continue. I thought it was too late for an abortion and I told myself that I would see and I would find an occasion to talk about it to someone. In fact, I never had the courage. As concerns [the father of the baby], I was afraid of his reaction and I thought my parents would not have understood. (Testimony in police custody, Ms. I.).

\section{The Psychosocial Profile of the Mothers}

This profile includes aspects of personality such as immaturity, dependence on others, withdrawal, inhibition, and self-disparagement, as well as aspects of relationships such as 
isolation, absence of communication, inexpressive or unfeeling family members, unstable couples. These women felt alone while living with a spouse and children. They very often had parents who could not or did not express feelings and emotions. They were frequently afraid of being abandoned by the father of their children or rejected by their family. They were invisible for their parents as well as for the men they lived with, and could only live out their pregnancy in secret. Indeed, it is clear that pregnancies that ended in neonaticide were pregnancies these women could not allow themselves to have, pregnancies they experienced under the tension of conflicting needs they could not talk about.

In view of this testimony, emotional deprivation seems to have begun early with Ms. N. and the parental 'guardians' were often at fault. [...] Her married life before the drama was not a model of success $[. .$.$] the dialogue in the couple had become$ practically nonexistent. We see a sad waste because neither one made the effort of confiding in the other nor expressing their feelings. A drama that is the result of a lack of communication. (Personality assessment of Ms. N.)

\section{Use of the Concept of Pregnancy Denial by the Different Actors in the Judicial Process}

Denial of pregnancy was cited in 15 of the 22 files. In 14 cases, it was cited in the psychiatric and/or psychological expert assessments, in 3 cases in police documents and in 7 cases in judicial documents. In 3 cases, pregnancy denial was mentioned only to be rejected. In one case, the expert psychologist stated it was not a denial of pregnancy but a denegation, whereas the indictment stipulated that it was a denial of pregnancy but associated it with dissimulation of pregnancy, which assumed the pregnancy was known. Denial of pregnancy was indeed associated with knowledge of the pregnancy in several files. Thus, for Ms. G., the expert noted that she "did not doubt that she was pregnant" but concluded in the "power of denial". The notion of denial was sometimes enlarged to include not only denial of pregnancy but also denial of reality or denial of the baby to be born. 
For the 3 "unknown pregnancies", experts concluded in a "classic denial of pregnancy" for Ms. W. and in a "complete denial" for Ms. U. (as noted, no assessment was done on Ms. V.). In two rulings for case dismissal for "insufficient evidence" concerning Ms. V. and W., it was explained that the mother was unaware of her pregnancy and that, in this case, her delivery took place "in exceptional circumstances".

Although the expert assessments identified 4 psychotic personalities, only one psychotic denial was diagnosed. It concerned a women who was aware of her pregnancy at 20 weeks of amenorrhea and felt fetal movement that she interpreted as such.

\section{Discussion}

Our study has shown neonaticide to be at least 5.4 times as frequent in France as recorded in official mortality statistics (Tursz \& Cook, 2011). This justifies reflecting on the most appropriate prevention strategies and, from this perspective, questioning the use of the concept of denial of pregnancy.

Our research benefited from having been carried out within a defined geographic population and we chose the judicial system as the information source with a view of reaching exhaustivity, since every known homicide of a newborn immediately triggers police and judicial action. However, in our sample, $25 \%$ of cases corresponded to the discovery of the body of a newborn child whose family was never found, a fact that raises at least two questions. The first concerns the unknown number of bodies never discovered and therefore the true frequency of neonaticides. The second question concerns the characteristics of the mothers that were never identified. We do not know if these women, who were better at hiding their crime, had demographic, socio-economic and psychological characteristics different from the mothers of $75 \%$ of the infants in our study population.

Studies on neonaticides are usually population-based and draw on judicial sources (Mendlowicz, Rapaport, Mecler, Golshan, \& Moraes, 1998; Putkonen, Weizmann-Henelius, 
Collander, Santtila, \& Eronen, 2007) and/or forensic sources (Herman-Giddens, Smith,

451 Mittal, Carlson, \& Butts, 2003; Mendlowicz et al., 1998) The under-evaluation of the problem

452 is always mentioned, especially in countries with legislation recognizing possible mitigating

453 circumstances (exhaustion, anxiety...) in a child's death, and thus often excluding the case

454 from statistics on neonaticide (Putkonen et al., 2007). Most studies on "denial of pregnancy"

455 originate in hospital gynecology/obstetrics departments (Friedman et al., 2007; Nirmal et al.,

456 2006; Pierronne, Delannoy, Florequin, \& Libert, 2002; Wessel \& Buscher, 2002). However,

457 population-based studies on deliveries cannot be exhaustive since they do not take into

458 account deliveries unassisted by health care professionals, including clandestine deliveries

459 followed by neonaticide. It thus appears that it is not possible to calculate the frequency of the

460 association between "denial of pregnancy" and neonaticide since all potential information

461 sources in the same geographical area are never investigated together and over a sufficient

462 time span to demonstrate a link between these two rare phenomena.

Aside from the prospective study in Berlin (Wessel \& Buscher, 2002), all studies cited

464 above were retrospective, as was our own. There is no standardization of judicial files in

465 France, which explains the absence of some information (such as the symptoms associated

466 with pregnancy), a problem found in all retrospective studies. However, judicial files relating

467 to serious cases are rich from several perspectives, and the existence of multiple expert

468 assessments, testimonies from the accused woman, but also from numerous witnesses, enables

469 a better understanding of the context surrounding the pregnancy and neonaticide and brings a

470 strong light to bear on the personality of the mothers.

What can our study say about "denial of pregnancy" as described in the literature and

472 whose definitions we used in analyzing our data? The notion of "pervasive denial" applies to

473 two cases, perhaps three, in which the pregnancy appears to have been completely unknown.

474 None of the cases in our study conformed to all criteria described by Miller (2003) or Beier et 
al. (2006), in particular, feelings of detachment from the infant were not always present and some mothers fantasized about the fetus. What we see are rather mechanisms of selfprotection, sometimes contradictory, sometimes underlain by the desire for a child whose existence it would be impossible to deal with, and one must indeed distinguish between pregnancy on the one hand and the desire to have a child on the other. Mothers appeared to disconnect pregnancy from childbirth. While a majority was conscious at one time or another of being pregnant, none of them anticipated or prepared for delivery, even though some of them wanted the child. They spoke to no one, did not assign a social existence to the pregnancy, did not register it and did not have prenatal care. In these circumstances, they could only give birth alone, in a panic and secretly and became victims of their own deception because they were unable to share their pregnancy with others.

Those around the mother often suspected the existence of the pregnancy, or even actually knew about it. However, no one did anything, reinforcing the women in their conviction that "they could not allow themselves" this pregnancy and they could not ask for help. The causes of neonaticide are in fact to be looked for prior to pregnancy among these women who appeared to lack knowledge about the realities of sexuality and affective relationships.

The age and occupation of the women in our study were as varied as those in the general population from the same geographical area (INSEE, 1999; Tursz \& Cook, 2011). Thus no distinctive socio-demographic profile could be identified, but our results suggest these women shared a similar psychosocial profile. Their relationships with their spouse/partner were especially marked by difficult and even absent communication. The latter characteristic, as well as psychological isolation and weak social support, are part of risk factors for poor and insecure maternal-fetal attachment (Cranley, 1984), itself hypothesized to 
play a role in fetal and/or child abuse (Brandon, Pitts, Denton, Stringer, \& Evans, 2009; Pollock \& Percy, 1999).

This psychosocial profile offers an important key to thinking about issues of prevention. In the context of a country with a wide range of free reproductive health services, these women did not use contraception effectively. Thus, at the community level, visibility of family planning centers should be improved (these are very active in France but are presently undergoing severe budget cuts) and sex education strengthened in junior and senior high schools by supplementary education on affective relationships, relations between the sexes, and parenthood.

On the clinical level, identifying these women within the framework of organized prenatal care is doubtless not possible. Therefore, thought must be given to various types of training and information for general practitioners in France who, at one time or another, see nearly all patients from all age groups. They could receive information on the particular psychological profile of neonaticidal mothers, and more significantly, general information on the importance of discussing patients' wishes and knowledge concerning reproductive health, regardless of the motivation behind their visit to the doctor.

Within the framework of an information campaign on risk factors for neonaticide, the concept of "pregnancy denial" appears to have little operational validity. There is no consensus on its definition and collaborating professionals from different disciplines have difficulty agreeing on the concept. Indeed, "denial of pregnancy" is a concept used by persons in the judiciary in a muddled and even contradictory manner, which raises the question whether it should be used in the judicial setting (especially as a tool in court battles). There is no indication it is a risk factor for neonaticide (women with pregnancy denial delivered in hospitals in studies cited above, those in our study did not present a typical picture of pregnancy denial). The term is unable to account for the complexity of emotions troubling 
524 women who perpetrate neonaticides. It polarizes attention only on the woman, giving her a

525 "mental illness" label, while those around her are cleared of responsibility and rarely affected

526 in spite of providing little social support during her difficult pregnancy. Thus, consideration

527 should be given to the meaning of the terms "denial of pregnancy" and "concealed

528 pregnancy". To the latter, we prefer "secret pregnancy", a more objective term than that of

529 concealed pregnancy, which has a pejorative connotation that may have legal implications,

530 with dissimulation suggesting premeditation of homicide in the extreme case. These secret

531 pregnancies should be accurately distinguished from "unknown pregnancies", a more

532 appropriate term than that of pervasive denial of pregnancy, to the extent that one cannot deny

533 something of which one has not had prior knowledge.

534 The cases of neonaticide described here show us there is no simple way of preventing

535 these situations. Neonaticide is not unconditionally linked to the denial of pregnancy, just as it

536 is not automatically the consequence of a rejection of the future child. Similarly, the desire for

537 a child does not necessarily lead to a realistic representation of the child and its needs. These

538 cases of neonaticide also teach us that the process of human reproduction is a profoundly

539 social process. The most important characteristic these pregnancies share is their lack of

540 social existence. A common feature among the mothers, as among women who suffer from

541 difficulties of prenatal attachment, is a lack of support from those around them. As seen in the

542 psychosocial profile we have described, the characteristics of their personalities and the nature

543 of their relationships to those around them are inextricably linked, leading to situations of

544 secrecy and isolation that can terminate in neonaticide. 
References

547 Article 122-1, French Penal Code, accessed December 1, 2011; available at: http://www.legifrance.gouv.fr/affichCodeArticle.do?idArticle=LEGIARTI000006417 $\underline{213}$

Bardou H, Vacheron-Trystram MN, \& Cheref S. (2006). Le déni en psychiatrie. Annales Médico-psychologiques, revue psychiatrique, 164(2), 99-107.

Beier, K. M., Wille, R., \& Wessel, J. (2006). Denial of pregnancy as a reproductive dysfunction: a proposal for international classification systems. J.Psychosom.Res., 61(5), 723-730.

Brandon, A. R., Pitts, S., Denton, W. H., Stringer, C. A., \& Evans, H. M. (2009). A History of the Theory of Prenatal Attachment. J.Prenat.Perinat.Psychol.Health., 23(4), 201-222.

Brezinka, C., Huter, O., Biebl, W., \& Kinzl, J. (1994). Denial of pregnancy: obstetrical aspects. J.Psychosom.Obstet.Gynaecol., 15(1), 1-8.

Cranley, M. S. (1984). Social support as a factor in the development of parents' attachment to their unborn. Birth.Defects.Orig.Artic.Ser., 20(5), 99-124.

Friedman, S. H., Heneghan, A., \& Rosenthal, M. (2007). Characteristics of women who deny or conceal pregnancy. Psychosomatics., 48(2), 117-122.

Friedman, S. H. \& Resnick, P. J. (2009). Neonaticide: Phenomenology and considerations for prevention. Int J Law Psychiatry, 32(1), 43-47.

Herman-Giddens, M. E., Smith, J. B., Mittal, M., Carlson, M., \& Butts, J. D. (2003). Newborns killed or left to die by a parent: a population-based study. JAMA, 289(11), 1425-1429. 
INSEE. (Annual). La France en faits et chiffres. Estimations annuelles de population au 1er janvier par région, département, âge et sexe, 1990-2006. Paris:Institut national de la statistique et des études économiques. Available from: http://www.insee.fr/fr/ffc/docs_ffc/elp_reg_dep.htm (Accessed May 5, 2010)

INSEE. (1999). Recensement de la population 1999. Exploitation complémentaire: population de 15 ans ou plus par région, sexe, âge et catégorie socio-professionnelle. Paris:Institut national de la statistique et des études économiques . Available from: http://www.insee.fr/fr/default.asp (Accessed May 5, 2010)

Mendlowicz, M. V., Rapaport, M. H., Mecler, K., Golshan, S., \& Moraes, T. M. (1998). A Case-Control Study on the Socio-Demographic Characteristics of 53 Neonaticidal Mothers. Int J Law Psychiatry, 21(2), 209-219.

Miller, L. J. (2003). Denial of pregnancy. In M. G. Spinelli (Eds.) Infanticide: Psychosocial and Legal Perspectives on Mothers Who Kill, (81-104). Washington, DC: American Psychiatric Publishing, Inc.

Nirmal, D., Thijs, I., Bethel, J., \& Bhal, P. S. (2006). The incidence and outcome of concealed pregnancies among hospital deliveries: an 11-year population-based study in South Glamorgan. J.Obstet.Gynaecol., 26(2), 118-121.

Pierronne C., Delannoy M-A., Florequin C., \& Libert M. (2002). Le déni de grossesse: à propos de 56 cas observés en maternité. Perspectives Psy, 41(3), 182-188.

Pollock, P. H. \& Percy, A. (1999). Maternal antenatal attachment style and potential fetal abuse. Child Abuse Negl., 23(12), 1345-1357.

Putkonen, H., Weizmann-Henelius, G., Collander, J., Santtila, P., \& Eronen, M. (2007). Neonaticides may be more preventable and heterogeneous than previously thought neonaticides in Finland 1980-2000. Arch.Womens Ment.Health, 10(1), 15-23. 
593 Spinelli, M. G. (2001). A systematic investigation of 16 cases of neonaticide.

$594 \quad$ Am.J.Psychiatry, 158(5), 811-813.

595 Stotland, N. E. \& Stotland, N. L. (1998). Denial of pregnancy. Primary Care Update for $596 \quad O B / G Y N S, 5(5), 247-250$.

597 Tursz A, Crost M, Gerbouin-Rérolle P, \& Cook JM. (2010). Underascertainment of child 598 abuse fatalities in France: retrospective analysis of judicial data to assess underreporting of infant homicides in mortality statistics. Child Abuse Negl, 34(7),

600 534-544.

601 Tursz A, Simmat-Durand L., Gerbouin-Rérolle P, Vellut N, \& Cook J. (2011). [Violent deaths 602 of infants: perpetrator careers, judicial handling of cases]. Paris:ONED. Available in French from: http://www.oned.gouv.fr/docs/rapports-rech/rapport_tursz_ao2007.pdf;

604 Tursz, A. \& Cook, J. M. (2011). A population-based survey of neonaticides using judicial 605 data. Arch.Dis.Child.Fetal.Neonatal.Ed., 96(4), F259-F263.

606 Wessel, J. \& Buscher, U. (2002). Denial of pregnancy: population based study. BMJ, 607 324(7335), 458 .

608 Wessel, J., Gauruder-Burmester, A., \& Gerlinger, C. (2007b). Denial of pregnancy-609 characteristics of women at risk. Acta.Obstet.Gynecol.Scand., 86(5), 542-546. 


\begin{tabular}{|c|c|c|c|c|c|c|c|c|}
\hline case & $\begin{array}{l}\text { DDP by } \\
\text { woman }\end{array}$ & age & $\begin{array}{l}\text { Family } \\
\text { status }\end{array}$ & $\begin{array}{l}\text { Occupational } \\
\text { status }\end{array}$ & Siblings & $\begin{array}{l}\text { Suivi médical } \\
\text { pendant } \\
\text { grossesse }\end{array}$ & $\begin{array}{l}\text { Connaissance } \\
\text { grossesse par } \\
\text { entourage }\end{array}$ & Signes de grossesse \\
\hline A & $\begin{array}{c}2 \mathrm{WA} \\
\text { (suspicion) }\end{array}$ & 18 & $\begin{array}{l}\text { lives with } \\
\text { parents }\end{array}$ & unemployed & 0 & $\begin{array}{l}\text { aucun suivi } \\
\text { médical }\end{array}$ & Yes (partner) & $\begin{array}{l}\text { Aménorrhée : oui } \\
\text { Prise de poids : oui } \\
\text { Mouvements fœtaux : non }\end{array}$ \\
\hline B & $2 / 3 \mathrm{WA}$ & 21 & $\begin{array}{l}\text { lives with } \\
\text { parents }\end{array}$ & $\begin{array}{c}\text { unemployed child } \\
\text { care worker }\end{array}$ & 0 & $\begin{array}{l}\text { aucun suivi } \\
\text { médical }\end{array}$ & no & $\begin{array}{l}\text { Aménorrhée : oui } \\
\text { Prise de poids : oui } \\
\text { Mouvements fœtaux : oui }\end{array}$ \\
\hline $\mathrm{C}$ & 4/5 WA & 26 & $\begin{array}{l}\text { lives in } \\
\text { couple }\end{array}$ & housewife & $\begin{array}{l}2 \text { (under child } \\
\text { protective services, } 1 \\
\text { still birth at home) }\end{array}$ & $\begin{array}{l}2 \mathrm{RDV} \\
\text { médicaux }\end{array}$ & no & $\begin{array}{l}\text { Aménorrhée : oui } \\
\text { Prise de poids : légère } \\
\text { Mouvements fotaux : ? }\end{array}$ \\
\hline $\mathrm{D}$ & $4 / 5 \mathrm{WA}$ & 31 & $\begin{array}{l}\text { lives with } \\
\text { her mother }\end{array}$ & cleaning lady & 1 living child & $\begin{array}{l}\text { aucun suivi } \\
\text { médical }\end{array}$ & yes & $\begin{array}{l}\text { Aménorrhée : oui } \\
\text { Prise de poids : oui } \\
\text { Mouvements fœtaux : oui }\end{array}$ \\
\hline $\mathrm{E}$ & $6 \mathrm{WA}$ & 19 & $\begin{array}{l}\text { lives with } \\
\text { parents }\end{array}$ & $\begin{array}{l}\text { highschool } \\
\text { student }\end{array}$ & 0 & $\begin{array}{l}1 \mathrm{RDV} \\
\text { médical }\end{array}$ & $\begin{array}{r}\text { Yes (mother's } \\
\text { family) }\end{array}$ & $\begin{array}{l}\text { Aménorrhée : oui } \\
\text { Prise de poids : oui } \\
\text { Mouvements fœtaux : ? }\end{array}$ \\
\hline $\mathrm{F}$ & $8 \mathrm{WA}$ & 21 & $\begin{array}{l}\text { lives with } \\
\text { parents }\end{array}$ & $\begin{array}{c}\text { highschool } \\
\text { student }\end{array}$ & $\begin{array}{l}1 \text { attempted } \\
\text { néonaticide }\end{array}$ & $\begin{array}{l}2 \mathrm{RDV} \\
\text { médicaux }\end{array}$ & $\begin{array}{r}\text { Suspicion (mother's } \\
\text { family) }\end{array}$ & $\begin{array}{l}\text { Aménorrhée : oui } \\
\text { Prise de poids : oui } \\
\text { Mouvements fœetaux : ? }\end{array}$ \\
\hline G & $9 \mathrm{WA}$ & 29 & lives with & waitress & 1 living child & aucun suivi & Suspicion ++ & Aménorrhée : oui \\
\hline
\end{tabular}




\begin{tabular}{|c|c|c|c|c|c|c|c|c|}
\hline & & & $\begin{array}{l}\text { son and } \\
\text { friends }\end{array}$ & & $\begin{array}{l}1 \text { neonaticide } \\
1 \text { enfant abandonné à } \\
\text { la naissance }\end{array}$ & médical & & $\begin{array}{l}\text { Prise de poids : oui } \\
\text { Mouvements fotaux : oui }\end{array}$ \\
\hline $\mathrm{H}$ & $9 \mathrm{WA}$ & 39 & $\begin{array}{l}\text { married, } \\
\text { lives in } \\
\text { couple }\end{array}$ & housewife & $\begin{array}{l}6 \text { living children } \\
1 \text { previous } \\
\text { neonaticide }+2 \\
\text { subsequent }\end{array}$ & $\begin{array}{l}\text { aucun suivi } \\
\text { médical }\end{array}$ & $\begin{array}{r}\text { Suspicion }++ \\
\text { (partner and } \\
\text { mother's family) }\end{array}$ & $\begin{array}{l}\text { Aménorrhée : oui } \\
\text { Prise de poids : ? } \\
\text { Mouvements fœtaux : ? }\end{array}$ \\
\hline $\mathrm{I}$ & $15 \mathrm{WA}$ & 21 & $\begin{array}{l}\text { lives in } \\
\text { couple }\end{array}$ & university student & 0 & $\begin{array}{l}1 \mathrm{RDV} \\
\text { médical }\end{array}$ & $\begin{array}{r}\text { Suspicion (partner }+ \\
\text { mother's family) }\end{array}$ & $\begin{array}{l}\text { Aménorrhée : oui } \\
\text { Prise de poids : oui } \\
\text { Mouvements fœetaux : ? }\end{array}$ \\
\hline $\mathrm{J}$ & $15 \mathrm{WA}$ & 32 & $\begin{array}{l}\text { lives in } \\
\text { couple }\end{array}$ & $\begin{array}{l}\text { middle-level } \\
\text { manager }\end{array}$ & 1 living child & $\begin{array}{l}\text { aucun suivi } \\
\text { médical }\end{array}$ & Suspicion (partner) & $\begin{array}{l}\text { Aménorrhée : oui } \\
\text { Prise de poids : légère } \\
\text { Mouvements fœetaux : ? }\end{array}$ \\
\hline $\mathrm{K}$ & 18/19WA & 44 & $\begin{array}{l}\text { married, } \\
\text { lives in } \\
\text { couple }\end{array}$ & $\begin{array}{l}\text { middle-level } \\
\text { manager }\end{array}$ & 3 living children & $\begin{array}{l}\text { aucun suivi } \\
\text { médical }\end{array}$ & $\begin{array}{l}\text { Suspicion à partir de } \\
\text { 27/28 SA (partner) }\end{array}$ & $\begin{array}{l}\text { Aménorrhée : spotting } \\
\text { Prise de poids : oui } \\
\text { Mouvements fœtaux : non }\end{array}$ \\
\hline $\mathrm{L}$ & $17 / 21 \mathrm{WA}$ & 17 & $\begin{array}{l}\text { lives in } \\
\text { couple with } \\
\text { mother-in- } \\
\text { law }\end{array}$ & sales lady & 0 & $\begin{array}{l}1 \mathrm{RDV} \\
\text { médical }\end{array}$ & oui & $\begin{array}{l}\text { Aménorrhée : oui } \\
\text { Prise de poids : ? } \\
\text { Mouvements fœtaux : oui }\end{array}$ \\
\hline $\mathrm{M}$ & $20 \mathrm{WA}$ & 23 & $\begin{array}{l}\text { married, } \\
\text { lives in }\end{array}$ & housewife & 3 living children & $\begin{array}{r}\text { aucun suivi } \\
\text { médical }\end{array}$ & $\begin{array}{r}\text { Yes (mother's } \\
\text { friend) }\end{array}$ & $\begin{array}{l}\text { Aménorrhée : from } 20 \mathrm{WA} \\
\text { Prise de poids : oui }\end{array}$ \\
\hline
\end{tabular}




\begin{tabular}{|c|c|c|c|c|c|c|c|c|}
\hline & & & couple & & & & & Mouvements fœtaux : oui \\
\hline $\mathrm{N}$ & $21 \mathrm{WA}$ & 28 & $\begin{array}{l}\text { lives in } \\
\text { couple }\end{array}$ & cleaning lady & 2 living children & $\begin{array}{r}\text { Aucun suivi } \\
\text { médical }\end{array}$ & Suspicion (partner) & $\begin{array}{l}\text { Aménorrhée : from } 18 \mathrm{WA} \\
\text { Prise de poids : ? } \\
\text { Mouvements fœtaux : oui }\end{array}$ \\
\hline $\mathrm{O}$ & $23 \mathrm{WA}$ & 37 & $\begin{array}{l}\text { lives with } \\
\text { her children }\end{array}$ & assistant director & 2 living children & $\begin{array}{r}\text { aucun suivi } \\
\text { médical }\end{array}$ & non & $\begin{array}{l}\text { Aménorrhée : from } 23 \mathrm{WA} \\
\text { Prise de poids : ? } \\
\text { Mouvements fotaux : ? }\end{array}$ \\
\hline $\mathrm{P}$ & $24 \mathrm{WA}$ & 31 & $\begin{array}{l}\text { married, } \\
\text { lives in } \\
\text { couple }\end{array}$ & $\begin{array}{l}\text { student training in } \\
\text { pharmaceutics }\end{array}$ & 2 living children & $\begin{array}{r}\text { aucun suivi } \\
\text { médical }\end{array}$ & oui & $\begin{array}{l}\text { Aménorrhée : non (règles } \\
\text { irrégulières) } \\
\text { Prise de poids : ? } \\
\text { Mouvements fœtaux : oui }\end{array}$ \\
\hline $\mathrm{R}$ & $27 \mathrm{WA}$ & 25 & $\begin{array}{l}\text { lives alone } \\
\text { with her } \\
\text { children }\end{array}$ & housewife & 2 living children & $\begin{array}{r}\text { aucun suivi } \\
\text { médical }\end{array}$ & non & $\begin{array}{l}\text { Aménorrhée : ? } \\
\text { Prise de poids : légère } \\
\text { Mouvements fotaux : oui }\end{array}$ \\
\hline $\mathrm{S}$ & $\begin{array}{c}27 \mathrm{WA} \\
\text { (suspicion) }\end{array}$ & 20 & $\begin{array}{l}\text { lives with } \\
\text { her mother }\end{array}$ & university student & 0 & $\begin{array}{l}\text { Aucun suivi } \\
\text { médical }\end{array}$ & $\begin{array}{r}\text { Suspicion (mother's } \\
\text { family) }\end{array}$ & $\begin{array}{l}\text { Aménorrhée : spotting } \\
\text { Prise de poids : légère } \\
\text { Mouvements fœtaux : non }\end{array}$ \\
\hline $\mathrm{T}$ & $30 \mathrm{WA}$ & 26 & $\begin{array}{l}\text { lives with } \\
\text { parents }\end{array}$ & nurse & 0 & $\begin{array}{r}\text { aucun suivi } \\
\text { médical }\end{array}$ & $\begin{array}{r}\text { Suspicion à partir } 37 \\
\text { SA (partner) }\end{array}$ & $\begin{array}{l}\text { Aménorrhée :spotting } \\
\text { Prise de poids : légère } \\
\text { Mouvements fœtaux : oui }\end{array}$ \\
\hline $\bar{U}$ & at delivery & 17 & $\begin{array}{l}\text { lives with } \\
\text { parents }\end{array}$ & $\begin{array}{l}\text { highschool } \\
\text { student }\end{array}$ & 0 & $\begin{array}{r}\text { aucun suivi } \\
\text { médical }\end{array}$ & non & $\begin{array}{l}\text { Aménorrhée : non } \\
\text { Prise de poids : non ? }\end{array}$ \\
\hline
\end{tabular}




\begin{tabular}{|c|c|c|c|c|c|c|c|c|}
\hline & & & & & & & & Mouvements fœtaux : non \\
\hline $\mathrm{V}$ & at delivery & 31 & $\begin{array}{l}\text { lives with } \\
\text { parents }\end{array}$ & secretary & 0 & $\begin{array}{r}\text { aucun suivi } \\
\text { médical }\end{array}$ & non & $\begin{array}{l}\text { Aménorrhée : non } \\
\text { Prise de poids : non } \\
\text { Mouvements fotaux : non }\end{array}$ \\
\hline W & at delivery & 24 & $\begin{array}{l}\text { married, } \\
\text { lives in } \\
\text { couple }\end{array}$ & $\begin{array}{c}\text { supermarket } \\
\text { employee }\end{array}$ & 3 living children & $\begin{array}{l}\text { aucun suivi } \\
\text { médical }\end{array}$ & non & $\begin{array}{l}\text { Aménorrhée : non } \\
\text { Prise de poids : non ? } \\
\text { Mouvements fœtaux : non }\end{array}$ \\
\hline
\end{tabular}

